\title{
NATIONAL SECURITY POLICY OF ITALY
}

\begin{abstract}
The security policy of the Republic of Italy serves as a key framework for the realization of fundamental interests in the country. There is no doubt that Italy's security policy has a specific place, given that it unites the country's overall efforts to adequately respond to threats. Undoubtedly, this contributes to the formation of security measures, to the action of the security sector within the constitutionally permitted framework. At the same time, security policy enables political goals to grow into a political security doctrine that seeks to produce an optimal concept and strategy of action to achieve the set goals. The complexity, variability and interdependence of the security system and security policy is the reason why these two segments in Italy have been analysed in one place. The analysis is supported by many questions and analogous to many answers related to the creation of security policy and the conditions in which it is realized.
\end{abstract}

Keywords: SECURITY, NATIONAL SECURITY, POLICY, SECURITY POLICY, ITALY

\section{Introductory Remarks}

The territory of the Republic of Italy covers an area of $301,340 \mathrm{~km}^{2}$, located in Southern Europe, of which $294,140 \mathrm{~km}^{2}$ belong to the mainland, while $7,200 \mathrm{~km}^{2}$ are under water, including Sardinia and Sicily. The Italian peninsula, or the Apennine Peninsula, is one of the three largest peninsulas in Southern Europe (Italian Peninsula, Encyclopaedia Britannica, 2020), and the other two are the Balkans (east) and the Iberian Peninsula (west). The Apennine Peninsula and the Apennines are a volcanic mountain range subject to frequent earthquakes, extending into the central Mediterranean Sea, northeast of Tunisia with a coastal area of 7,600 km, a border line of 1,836 km and 2,400 km road routes 1 , that is, it stretches from the region of the river Po, about $960 \mathrm{~km}$ south and extends to the length of the peninsula, and has a maximum width of $240 \mathrm{~km}$, while the lowlands are mostly along the coast. It is surrounded on the east by the Adriatic Sea, on the south by the Ionian Sea, and on the west by the Tyrrhenian and Ligurian Seas. On the peninsula, much of the territory belongs to Italy, and a small part includes the independent republic of San Marino, as well as one of the holiest sites of Christianity, the Vatican City, which testifies to its rich history and imposing spiritual heritage, with a unique collection of art and

${ }^{1}$ White Paper for International Security and DefenseDefence, Ministry of Defence of the Republic of Italy, 2015. 
architecture, masterpieces located within the borders of this small country ( $V a$ tican City, UNESCO, 2020). Italy has international borders with Austria, France, the Holy See (Vatican City), San Marino, Slovenia and Switzerland. It shares maritime borders with Albania, Algeria, Croatia, Greece, Libya, Malta, Montenegro, Spain and Tunisia. Two of the largest Mediterranean islands belong to Italy: Sardinia to the west and Sicily to the south (Italy, Encyclopaedia Britannica, 2020). Italy ranks $12^{\text {th }}$ among countries with annual firepower calculations (Global Firepower, Italy, 2019).

According to the estimates, by July 2020, Italy should have about 62, 402,000 inhabitants. Of the total population, $83.3 \%$ are Christians (mostly Roman Catholics with very small groups of Jehovah's Witnesses and Protestants), $3.7 \%$ are Muslims, $12.4 \%$, and no other $0.6 \%$ (2010 estimate) (The World Factbook). The gross domestic product in 2017 was estimated at \$ 2,317 trillion. The gross national product per capita in 2017 was \$ 38,200 (The World Factbook CIA: Italy, 2020).

\section{Institutions for Creation of Security Policy}

The central bodies for creating security policy in Italy are: the Parliament, the President of the Republic and the Council of Ministers.

The Italian Parliament (Italian: Parliamento italiano) is the national parliament of the Italian Republic. It is the representative body of the Italian citizens and is the successor to the Parliament of the Kingdom of Sardinia (18481861), then to the Parliament of the Kingdom of Italy (1861-1946), the Transitional National Council (1945-1946) and the Constituent Assembly (1946-1948).

Parliament has bicameral legislation, consisting of the House of Representatives - Camera dei Deputati (with 630 members or deputies elected on a national basis) and the Senate of the Republic - Senato della Repubblica (with 315 members or senators elected on a regional basis, and a small number elected senators from the social life or senatori a vita, or appointed ex officio. So, the legislative function is practiced collectively by both houses. The two houses are independent of each other and never meet together, except under the circumstances set out in the Italian Constitution. ${ }^{2}$ Under the 1948 Republic Constitution, both houses of the Italian parliament have the same powers; perfect bicameralism that has been codified in its current form since the enactment of the Statute of Albert in 1849 and has been actualized since the end of the fascist dictatorship of the 1920s and 1930s from the previous century.

The Parliament has a number of powers that, as prerogatives, bind it so that it can declare martial law and give the necessary powers to the Government. Parliament is authorized by law to discuss all issues in the field of security and defence that require a legal solution. It also decides on changing borders and new legislation. The Parliament also passed a law granting amnesty and

${ }^{2}$ Articles 56, 57, 58 and 59 from the Constitution of the Italian Republic. 
pardon by a 2/3 majority of both houses. Each year, the Parliament adopts the budget and financial reports submitted by the Government, ${ }^{3}$ and within that framework the budget for the security sector.

The President of Italy, officially the President of the Italian Republic (Italian: Presidente della Repubblica Italiana) is the Head of State of Italy. In that role, the incumbent represents national unity and guarantees that Italian policy is in line with the Italian Constitution. The president's term is seven years. This prevents each holder of the presidency from being re-elected by the same members of the two houses of the Italian Parliament (the House of Representatives and the Senate of the Republic) for a term of five years. This setup also provides some guarantee of excessive political connections with the bodies that decide on the appointment. The term of the Italian president may end with voluntary resignation, death, permanent disability due to serious illness or dismissal for treason or violation of the Constitution. ${ }^{4}$

The Constitution establishes the duties and powers of the President of the Republic in several areas such as foreign affairs where he has classical powers: accredits and receives diplomatic officials, ratifies international agreements, etc. Thereafter, he declares martial law, by decision of the Parliament, and within the framework of parliamentary work: nominates up to five life senators, convenes parliamentary houses at an extraordinary session and dissolves them, calls for elections and sets a date for the first meeting of the new homes. The president, through his legislative powers, has the authority to present proposed laws to parliament, promulgate laws passed by parliament, submit them to homes (with explanation) and request a review of the law (once per law), has the responsibility for people's sovereignty, calls out to a referendum (EURECNET. National Information: Italy, 2020), while in the executive affairs and the official protocol also has the following powers: appoints the Prime Minister of Italy and appoints Ministers after consultation with the Prime Minister; accepts the oath of the Government; receives resignation from the Government; chairs the Supreme Defence Council, which also creates a national security policy, and commands the armed forces. In the Supreme Defence Council, the President of the Republic obtains detailed information on the government's orientations on security and defence issues, so that he can adequately perform the complex function of balancing and guaranteeing which is designated by the Constitution. In general, the Council is the permanent institutional body in which multidisciplinary debate and analysis of security and defence and security policy issues will take place.

The Council of Ministers (Italian: Consiglio dei Ministri, CdM) is the main executive body of the Government of Italy. It consists of the President of the Council (that is the Prime Minister), all the Ministers and the Undersecretary of the President of the Council. ${ }^{5}$ The Office of the Council of Ministers is re-

\footnotetext{
${ }^{3}$ Articles 78, 79, 80, 81 and 82 from the Constitution of the Italian Republic.

${ }^{4}$ Republic of Italy Senate. Constitution of the Italian Republic.

${ }^{5}$ Council of Ministers of the Republic of Italy.
} 
gulated by the Constitution and consists of the President of the Council of Ministers, who meets with the Council and Ministers appointed by the President of Italy after post-election consultations with leaders of parliamentary groups, Speakers of Parliamentary Homes and former Presidents of the Republic. The Prime Minister is confirmed by an initiative for a vote of confidence (nominal vote) in both houses of Parliament within 10 days of being sworn in by the Government in accordance with the Constitution. The ministers are appointed by the President of Italy on the proposal of the Prime Minister. According to the Constitution, the President of the Republic has the power to question the election of a Minister, if there is a real basis, and until an agreement is reached, the Minister of the relevant ministry will not be able to be appointed. All powers of the Council of Ministers remain in the hands of the President of the Republic until the Ministers take over their offices. ${ }^{6}$

In accordance with Article 95 of the Constitution of the Italian Republic, the President of the Council of Ministers implements and bears responsibility for the general policy of the Government. The President of the Council ensures the coherence of political and administrative policies by promoting and coordinating the activities of ministers. The Prime Minister is also responsible for creating and implementing the national security policy and this responsibility is shared with the Council of Ministers and they are individually responsible for their actions in the relevant ministries, especially the security and defence departments.

In the realms of security and defence, the government has a number of powers. The following powers are assigned exclusively to the President of the Council of Ministers, as follows: a) supervision and full responsibility for security and intelligence policy in the interest and defence of the Republic and its basic democratic institutions established by the Constitution; b) application of the status of state secret and protection of state secrets; c) a confirmation of a call for state secret status; d) appointment and dismissal of the Director General and one or more Deputy General Directors of the Security Intelligence Department; e) appointment and dismissal of the directors and deputy directors of the security intelligence services; $\mathrm{f}$ ) determination of the annual amount of financial resources to be allocated to the security-intelligence services, which amount will be submitted to the parliamentary commission (Borghetto, E. 2018). In order to exercise the powers set out in paragraphs (b) and (c) above, the President of the Council of Ministers shall determine the criteria governing the application and invocation of the status of a state secret and shall issue the provisions necessary for the administrative protection of state secrets as well as those that address the issue and revocation of the security clearance.

The President of the Council of Ministers coordinates security intelligence policies, issues directives and, after prior consultation with the Interresor (Inter-Ministerial) Security Committee of the Republic, issues all necessary me-

${ }^{6}$ Council of Minister of the Republic of Italy. Cabinet. 
asures for the organization and operation of the Republic's intelligence and security system (ENISA European Union: CIIP Governance, 2020). Following prior consultation with the Inter-Ministerial Committee on Security of the Republic, the President of the Council of Ministers issued directives to the Ministry of Security and Intelligence (DIS) and to the Security and Intelligence Services to strengthen security intelligence activities to protect critical infrastructure and national computer defence and security. ${ }^{7}$

According to the analysis of the constitutional and legislative position in the chain of command in the Republic of Italy, there is a very delicate institutional issue that has lingered on since the birth of the Republic. Namely, Italy has a parliamentary system: the Prime Minister - and the ministers on the proposal of the Prime Minister - are appointed by the President of the Republic. The government takes office after a vote of confidence in both houses of parliament. In this context, the prime minister is primus inter pares (the first among equals) because he has only limited hierarchical responsibilities over ministers (he cannot dismiss them). This complicates the chain of command in the military. The Commander-in-Chief is the President of the Republic, who has no strategic or operational role. The operational commander is the Chief of the General Staff for Defence, who is accountable to the Minister of Defence, but the Minister of Defence is not accountable to the Prime Minister. What is missing is a legal mechanism that gives the Cabinet as a whole authority to direct the engagement of the military instrument. There is a broad agreement on the need to clarify this issue with the chain of command, as a key precondition for the more efficient use of the armed forces for peacekeeping operations, as well as for other emergencies (United Nations Peacekeeping, Italy, 2020).

\section{National Security Policy of the Republic of Italy}

Italy is one of the founding members of the EU and NATO. In terms of the political areas for which Italy is developing governance mechanisms with modern open issues, these include issues related to respect for human rights, disarmament, environmental protection, energy security, the fight against terrorism, migration, and so on.

In terms of foreign policy, the Republic of Italy develops economic, cultural and scientific diplomacy, through bilateral cooperation and through the institutions of the EU, G8, G20, OSCE, and other international organizations. ${ }^{8}$ The legal framework for co-operation is provided for in Article 11 of the Italian Constitution, which states that "Italy will agree to [the] restrictions on sovereignty that may be necessary to ensure peace and justice among peoples." Italy will promote and encourage international organizations that achieve such goals." 9

\footnotetext{
${ }^{7}$ Ministry of the Interior of Italy.

${ }^{8}$ Ministry of Foreign Affairs and International Cooperation.

${ }^{9}$ Ibid.
} 
Participation in international peacekeeping operations has been a constant in Italy's foreign policy since the early 1980s. The first deployment of post-World War II military units took place in 1982, in the midst of the Lebanese Civil War, followed by the Israeli invasion of Lebanon and the devastating siege of Beirut. The Italian government has responded to a request for help from Lebanese authorities and deployed troops to Beirut as part of the Multinational Forces in Lebanon, which included French, British and American contingents (Camporini, 2019). Since then, the Italian armed forces have engaged in a number of international efforts to restore peace and security around the world, in Kuwait (1990-91), Somalia (1992-95), in all conflict zones in the Western Balkans and East Timor (East Timor). 1999- 2000), etc. Today, Italy makes a significant contribution to Western missions in the United Nations and ranks second after the United States as the largest contributor of NATO-led missions. Italy is not a nuclear power, so it cannot rely on nuclear intimidation as a nuclear deterrent to prevent potential attacks, so effective air and missile defence are perceived as an essential element for Italy's future military position. (European Defence Agency: National Policies and Strategies, 2020).

In the absence of a direct threat to its national security, Italy has chosen to declare a series of issues that are important to its national interests (Ignazi, Giacomello \& Coticchia, 2012). Italy is projecting itself as a middle-power country participating in NATO's major security alliance and the European integration process. At the same time, Italy, in its strategic commitments, intends to take a greater profile and greater responsibilities in the geographical areas in which it has immediate security interests. (Zapotoczny, 2018). Regions, including the Mediterranean, such as the Persian Gulf, Central / Eastern Europe, the Balkans and Turkey, with pressure on the Caspian Sea and Central Asia, are considered to be the nerve centre of future European stability and Italian interests. In terms of foreign and security policy, Italy does not see itself as an independent actor acting in isolation in any regional confrontation, but as part of a community of European nations working together to resolve issues and differences that undermine the political and economic stability of Europe.

Italy is an important economic and political partner of the United States. Italy's immediate proximity to areas of tension in the Balkans, the Eastern Mediterranean and North Africa underscores its strategic importance. Italy has worked with the United States to promote reconstruction, democratization and stability in Iraq, Afghanistan and Central and Eastern Europe, in implementing the Dayton Accords in Bosnia and Herzegovina and the success of the Middle East peace process. Italy has played a key role in NATO's action in Kosovo and in managing the refugee crisis, as well as in efforts for economic and political stabilization in Albania. Italy has played a central role in the growth of the European Union, supporting European economic and political integration and advocating a stronger European security and defence identity within NATO.

In recent years, Italy has managed to build a modern concept of national security policy based on ensuring peace and security in the country and in the 
international community to respond to the challenges and threats in the new security environment. The concept rejects the militarized approach, that is in the White Paper on International Security and Defence from 2015, the politicalstrategic views on the development of the army and its use for the purposes of the Italian foreign and defence policy were outlined. The White Paper is quite coherent in trying to define priorities for Italian defence policy, as well as the Ministry of Defence's reform guidelines, based on national interests and the resources that will be available to the armed forces in the coming years (The Italian White Paper for International Security and Defence, 2015).

Based on the strategic position and assessment of the international security environment, which emphasizes the growing danger of asymmetric threats, Italy pays due attention to the threats of terrorism, transnational crime, illegal migration, human trafficking, national organized crime, cyber threats, etc. The terrorist attack in recent years in some metropolises around the world has confirmed that terrorism is not dead. Indeed, despite al-Qaeda's decline and Islamic State's military defeats, the two groups are still active in waging war on their "distant enemies" in the West. However, a large, influential European country like Italy is thought to have been left without a terrorist attack (Beccaro, Bonino, 2020; ISPI). It is important to note that there have been minor terrorist attacks in Italy, even if they are not as bloody or well-organized as those in other European countries. In addition, "no terrorist attacks" does not mean that there are no terrorist activities. In this regard, it should be noted that in recent years the Italian security forces have conducted several operations. For example, in June 2017 in Alexandria, Lara Bombonati was arrested for joining Islamist militias in Syria with her husband Cassio, who was killed in the same country. She was a member of the jihadist cell with links to Italy and Europe. In April 2018, 13 people (Tunisians, Moroccans and Italians) were arrested during the Scorpion / Fish 2 operation, using fast motorcycles to smuggle cigarettes and illegal immigrants from Tunisia. Further investigation revealed that members of the transnational criminal group had links to terrorism. The operation is also significant because it sheds some interesting light on related terrorist crimes, namely the link between illegal human trafficking (tobacco, weapons, drugs and people) in the Mediterranean and the possibility of such activities being funded by terrorist groups. According to Franco Gabrielli, head of the Italian police, it is currently impossible to say that there are close ties between the two phenomena (crime and terrorism). However, investigations clearly show that in some cases there are forms of cooperation, although this is not an established cooperation, but it seems to be a kind of beneficial marriage that is the basis for certain operations. In the spring of 2016, due to an FBI warning, Italian security forces found Moftah al-Slake, a Libyan illegal immigrant who was fighting in Libya for Ansar al-Sharia and who had already carried out two reconnaissance missions at a shopping centre near Genoa. The Genoa operation in 2017 was aimed at Nabil Benamir, a Moroccan citizen with extensive experience in setting up devices and fighting in Syria and Iraq with ISIS. According to investigators, his goal was to train ISIS members to make and use explosives (Terrorism: Tackling the Threat to Italy's Excepytionalism. Beccaro, Bonino; ISPI, 2020). 
In the context of the new security challenges, Italy believes that at a time of increasing dependence on digital solutions in an increasingly interconnected world, it has become clear that society has become vulnerable. The current technological revolution and its global effects imply the need in Italy and elsewhere to address common opportunities and challenges through a systemic approach that must include public institutions, companies, academia and individual citizens. A common, general challenge when it comes to computer security is to create a clear legal framework and institutional architecture in order to identify all entities responsible for computer security issues. Italy has made great strides in creating a computer security ecosystem and a new management / computer security strategy in the belief that a transparent and protected environment can contribute to creating a positive business environment, favourable for the birth and development of new companies and investment in innovation (Cybersecurity in Italy, New opportunities for business, September 2019, 4-5).

In 2017 and 2018, Italy directed and strengthened its computer security structure in order to strengthen its computer capabilities. Areas of priority for the development of computer security knowledge include issues related to defence and national security, critical networks that provide basic services to end users, and the protection of national businesses. When it comes to ICT, computer security is also fundamental to protecting citizens' rights. We live in an era in which state oversight forces are expanding, where global giants on the Internet are collecting and recording data on our behaviour, keeping track of our most intimate beliefs and behaviours, which can allow others to manipulate (such as in the case of known "fake news" as a phenomenon) and use them to intimidate us. Cyber security is increasingly focusing on the financial sector, where cyberattacks are aimed at three specific purposes: organizing large-scale financial data thefts, temporarily damaging banking and insurance services, and disrupting the integrity of data in the banking system. Italian companies are enthusiasts of sophisticated computer protection solutions, and at the same time, manufacturers and exporters of advanced technologies, position Italy among the most important players in the global cyber market. (Ibid. p. 5-12).

\section{Conclusion}

Italy's national security policy is a key state and institutional issue. Therefore, building a policy of national security is primarily a political and national issue, which means creating a concept of well-thought-out ideas, and their implementation should include all relevant entities in the country.

In general, Italy's national security policy is based on a realistic view of the security challenges facing the country, and overall efforts are aimed at optimizing resources to ensure the necessary security in Italy. Security policy also includes important decisions by the President of Italy and the Government on threats that could seriously affect the internal and external security of the country. It is a clear synergy and dialectic to build a clear state policy based on a coherent approach to pre-determined states to develop an appropriate security 
approach. Therefore, Italy's security policy does not mean that it is only a matter of perceiving the needs and priorities of national security, but also an effort to unite the total efforts to achieve vital interests, and not to perceive partial interesting positions.

So Italy's effective security policy cannot succeed if it is not based on a pragmatic approach. It is a substrate in shaping its philosophy framework and serves as an appropriate basis for decisively defining the responsibilities of all security actors to address complex security issues.

\section{References:}

AndreAtTA, F. 2001. "Italy at a Crossroads: The Foreign Policy of a Medium Power after the End of Bipolarity", Daedalus 130(2): 45-54.

BALOSSI-Restelli, M., L. (2013) "Italian Foreign and Security Policy in a State of Reliability Crisis?" Modern Italy 18(3): 255-267.

Borghetto, E. (2018) "Delegated Decree Authority in a Parliamentary System: The Exercise of Legislative Delegation in Italy (1987-2013)". The Journal of Legislative Studies 24(2): 179-196.

ButTON, M. \& STIERNSTEDT, P. (2019) Comparing Private Security Regulation in the European Union. Routledge.

Croci, O. (2003) "Italian Security Policy after the Cold War" Journal of Modern Italian Studies 8(2): 266-283.

Crociani, P. \& Battistelli, P. (2013) Italian Navy and Air Force Elite Units E Special Forces 1940-45. Bloomsbury Publishing.

Di CAmillo, F. ET AL. (2014) The Italian Civil Security System. IAI Research Papers. Edizioni Nuova Cultura, Roma.

Di Camillo, F., \& Marrone, A. (2014) The Italian Civil Security System. Programme 7th Project "Analysis of Civil Security Systems in Europe" (ANVIL) Edizioni Nuova Cultura.

Domenico, R., P. (2002) The Regions of Italy: A Reference Guide to History and Culture. Greenwood Press, London.

DubBer, M. \& HöRnLE, T. (2014) Oxford Handbook of Criminal Law. Military Justice.

FIELDS, C., ET AL. (2013) Handbook of Policing in Central and Eastern Europe. Springer, New York.

Giacomello, G., VerbeeK, B. (2011) Italy's Foreign Policy in the 21 $1^{\text {st }}$ Century: the New Assertiveness of an Aspiring Middle Power. Lexington Books, Plymouth, UK.

IgnaZi, P., Giacomello, G., \& COTICchia, F. (2012) Italian Military Operations Abroad: Just Don't Call it War. Basingstoke: Palgrave. 
ItALy INTELLIGENCE Security Activities and Operations. Handbook Volume 1. Strategic Information and Regulations. International Business Publications, Washington DS, USA - Italy.

Labanca, N. (2011) Defense Policy in the Italian Republic: Frames and Issues. UNISCI Discussion Papers No.25.

Minalache, C., O. (2017) NATO's 'Out of Area' Operations: A Two- Track Approach. the Normative Side of a Military Alliance. Croatian International Relations Review - CIRR XXIII (80): 233-258.

SIDOTI, F. (2009) The Italian Intelligence Services. VS Verlag für Sozialwissenschaften.

WALSTON, J. 2011. "Italian Foreign Policy since the End of the Cold War." In Italy in the Post-Cold War Order: Adaptation, Bipartisanship, Visibility, edited by Carbone, M., 57-74. Lanham, MD: Rowman.

ZAPOTOCZNY, W., S. (2018) The Italian Army in North Africa: A Poor Fighting Force or Doomed by Circumstance. Fronthill Media.

\section{Internet Sources:}

Constitution of the Italian Republic. Senato della Repubblica. https://www.wipo.int/edocs/lexdocs/laws/en/it/it037en.pdf

Encyclopedia Britannica. Italy. https://www.britannica.com/place/Italy

High Council for the Judiciary: About the Council:

https://Www.Csm.It/En/Web/Csm-International-Corner/High-Council-

For-The-Judiciary/About-The-Council

Italian Peninsula. https://www.britannica.com/place/Italian-Peninsula

Italy - Defense and Security: Internal Violence Challenging National Security. (Strategy, Performance and Risk Analysis)

https://www.prnewswire.com/news-releases/italy---defense-andsecurity-internal-violence-challenging-national-security-strategyperformance-and-risk-analysis-300553436.html

Italy Military Strength (2020). Global Firepower.

https://www.globalfirepower.com/country-military-strengthdetail.asp?country_id=italy

Italy: The Chief of the Italian Defense Staff Strategic Concept.

https://css.ethz.ch/en/services/digitallibrary/publications/publication.ht $\mathrm{ml} / 156795$

Law 124/2007. https://www.sicurezzanazionale.gov.it/sisr.nsf/english/law-no124-2007.html\#Chapter_I

Ministero Degli Affari Esteri e della Cooperazione Internazionale. Policy Areas. https://www.esteri.it/mae/en/politica_estera/temi_globali (26.4.2020)

Ministero Della Difesa. Carabinieri.

http://www.carabinieri.it/multilingua/en/welcome 
Ministry of Defense. http://www.esercito.difesa.it/EN

National Policies and Strategies. European Defense Agency. https://www.eda.europa.eu/industry-info/directories/nationaldirectories/national-policies-and-strategies (26.4.2020)

Republic of Italy. https://www.globalsecurity.org/military/world/europe/it.htm Review of the Italian National Civil Protection System. OECD. https://www.oecd.org/italy/reviewoftheitaliannationalcivilprotectionsys tem.htm

The Chief of staff of the Italian Army. http://www.esercito.difesa.it/en/organization/The-Chief-of-GeneralStaff-of-the-Army

The Intelligence and Military Security Service (SISMI) Servizio per le Informazioni e la Securezza Militare.

https://www.globalsecurity.org/intell/world/italy/sismi.htm

The Italian White Paper for International Security and Defense. Instituto Affari Internazionali.

https://www.iai.it/en/pubblicazioni/italian-white-paper-internationalsecurity-and-defence

The Role of the Financial Intelligence Unit.

https://uif.bancaditalia.it/sistemaantiriciclaggio/uifitalia/index.html?com .dotmarketing.htmlpage.language $=1$

The World Factbook. Europe: Italy.

https://www.cia.gov/library/publications/the-worldfactbook/geos/it.html

Italian Ministry of Interior. Department for Civil Liberties and Immigration. European Commission.

https://ec.europa.eu/knowledge4policy/node/6753_es

Sistema di Informazione per la Sicurezza della Repubblica. https://www.sicurezzanazionale.gov.it/sisr.nsf/english.html

Cyber Crime Legislation. Cyber Crime Policies/ Strategies. Italy. https://www.coe.int/en/web/octopus/countrywiki//asset_publisher/hFP A5fbKjyCJ/content/italy/pop_up?inheritRedirect=false 